SKENE, L, 'Proprietary rights in human bodies, body parts and tissue: Regulatory contexts and proposals for new laws’ (2002) 22 (1) Legal Studies 102-127

\title{
Proprietary rights in human bodies, body parts and tissue: Regulatory contexts and proposals for new laws
}

\author{
Loane Skene, Professor of Law, University of Melbourne
}

This paper examines the law on the proprietary rights of people in respect of their bodies, body parts and tissue. Proprietary rights include rights of ownership and control. The paper argues that the context in which judicial decisions are made and policy recommendations are developed sometimes results in a patchwork of legal principles. Being aware of the context in which different aspects of the law have been developed enables us to understand why principles have been developed, what is needed to reconcile them and how we can establish a coherent regulatory regime. The paper then proposes such a scheme to deal with property and control rights in this area. It argues that people (or the personal representatives of people who have died) should have a personal autonomy right to be consulted about the use of their corpse or their excised body parts or tissue in teaching, research and commercialisation of biological inventions, and to refuse or to impose conditions. They should not, however, have a right of ultimate ownership in their corpse, body parts or tissue, except for the limited right of personal representatives to gain possession of bodies and body parts of people who have died for burial or cremation if they so wish. That right should not extend to tissue preserved on slides, in paraffin wax or similar format. That tissue should be subject to proprietary interests in favour only of the hospital, research institute, its staff or the people to whom they transfer it. The same rule should apply to bodies or body parts held by a hospital or research institute with the consent of the person concerned, though the bodies or body parts may ultimately have to be returned for burial or cremation. Tissue removed under a statutory requirement without consent, such as for coronial investigation or forensic tests, should be used only for the purposes prescribed by the relevant legislation.

\section{INTRODUCTION}

This paper examines the proprietary rights that people have in relation to their bodies after death and their excised body parts and tissue. ${ }^{1}$ This matter has been considered in a relatively small number of judicial decisions during the last century in Britain, the

\footnotetext{
${ }^{1}$ Although cumbersome, I use the terms "bodies", "body parts" and "tissue” throughout this paper to emphasise their difference. The term "human material” was used in the Interim Report of The Inquiry into the management of care of children receiving complex heart surgery at The Bristol Royal Infirmary, chaired by Professor Ian Kennedy, May 2000; available at http://www.bristolinquiry.org.uk/index.htm. The Interim Report published in relation to the Inquiry, Removal and Retention of Organs, May 2000, is later called "Bristol Report”. It defined "human material” to include tissue, organs and parts of organs and amputated limbs: I believe this elision of tissue preserved in a laboratory, for example on glass slides, with larger parts of human bodies, is unfortunate and should be avoided.
} 
United States and Australia. ${ }^{2}$ The judgments reach different conclusions on whether these things can be property and who is entitled to proprietary rights (ownership or control) in respect of them. More recently however, some courts have recognised that human tissue is property, at least for some purposes, and that the person from whom it came is not always entitled to get it back, to require that it be destroyed or to exercise any other proprietary rights over it. In contrast, there has been a spate of government and independent inquiries, some leading to proposals for policy development in relation to the control and disposal of human tissue. Most notable are the highly publicised Bristol Infirmary Inquiry, chaired by Professor Ian Kennedy (the Bristol Inquiry) ${ }^{3}$ the Alder Hey Inquiry, chaired by Michael Redfern QC, concerning the retention of body parts and tissue at Alder Hey Hospital in Liverpool (the Alder Hey Inquiry); ${ }^{4}$ and the Independent Review Group on the Retention of Organs at PostMortem in Scotland (the McLean Inquiry), chaired by Professor Sheila McLean. ${ }^{5}$ These inquiries appear to recognise rights in relation to excised body parts and tissue on the part of the people from whom they came, at least in the context of post-mortem examinations, without examining the legal basis of those rights, which was outside their terms of reference.

The aim of this paper is to examine the reported cases and the findings and recommendations of the inquiries, especially in relation to the "context" in which the cases were decided and the recommendations made. ${ }^{6}$ I argue that each is a product of its circumstances and that we should be wary of adopting any decision or policy recommendations on the basis of a single source. Instead, we should look broadly across a range of relevant areas of law, bearing in mind the legal principles that are most likely to achieve the ends we desire. To illustrate what those ends might be, I pose a series of questions concerning different types of body parts and tissue, removed in different circumstances for different purposes, suggesting what I believe are the intuitively "right" answers.

In my view, we need legal principles that promote health care, teaching, medical research and the development of new drugs, but at the same time take account of people's sensitivity concerning the removal, retention and use of human bodies, excised body parts and tissue. I argue that an appropriate balance can be achieved by acknowledging that people should have personal autonomy rights over their bodies and excised body parts and tissue but not proprietary rights (ownership or ongoing

\footnotetext{
${ }^{2}$ For brevity, the paper is confined to these three common law jurisdictions.

${ }^{3}$ Above, $\mathrm{n} 1$.

${ }^{4}$ The Royal Liverpool Children's Inquiry; the report of this inquiry, published on 30 Jan 2001, is later called “Alder Hey Report”. It is available at http://www.rlcinquiry.org.uk/

${ }^{5}$ :Report of the Independent Review Group on the Retention of Organs at Post-Mortem, Jan 2001. It is available at:

http://www.show.scot.nhs.uk/scotorgrev/Documents/Review\%20Group\%20on\%20ROPM\%20Report.p df.

${ }^{6}$ It may be argued that the "context" in which I have suggested the various cases were decided is less clear than the one that I have described in each case - hygiene and respect for the dignity of the person; patents and biotechnology; pragmatism in the use of forensic samples; and public outcry at the retention of deceased children's body parts after post-mortem without parents' consent or knowledge. "Regulatory contexts" may sometimes overlap. Judicial decisions or policy recommendations may have more than one foundation, either stated or implicit. However, in suggesting the various contexts in which the cases described in this paper were decided, I have relied not only on my own response, but also on the comments in the cases and the reports of the Inquiries, which indicate their thinking. These are highlighted in the text and notes.
} 
control), especially over their excised, preserved tissue. (This is subject to bodies and body parts of deceased people being returned to personal representatives on request for burial or cremation.) I explain the extent and implications of the proposed rights.

The paper commences by describing the different types of human tissue that are commonly held by hospitals, laboratories and others, to remind readers that the medical context in which we are considering ownership and control of human body parts and tissue is far wider and more complex than the post-mortem context publicised in the Bristol, Alder Hey and McLean Inquiries. I note also in this section the different forms of legal authority for taking and withholding tissue. I then examine the legal cases and the various inquiries into hospital practices, emphasising in relation to each, the context in which it occurred. Finally, I submit my own proposals for what the law should be, endeavouring to reconcile the statements and recommendations, taking account of their respective regulatory context.

\section{THE MEDICAL CONTEXT}

British readers considering the retention of human bodies, body parts and tissue in 2001 will inevitably think at once of the brains, organs and even whole fetuses stored at the Bristol Infirmary, Alder Hey Hospital and other places, ${ }^{7}$ especially after the death of children. Those instances are discussed more fully later in the paper but the collections of laboratories and hospitals are far more diverse. In addition to organs or parts of organs removed during surgery or after death, there are organs, stored.blood, serum, skin and other living body parts for use in medical care or research; tissue preserved on slides for pathology tests for a range of purposes (therapeutic tests during life and after death including genetic tests with implications for relatives, forensic tests, such as tests for alcohol or drugs; identification of criminal suspects; and paternity; and samples to be submitted in evidence in medical negligence cases); and other living cells that can be reproduced indefinitely for research, such as cell lines and pluripotent stem-cells.

\section{THE LEGAL ISSUES}

There are many significant legal issues concerning rights of ownership and control in relation to stored body parts and tissue. ${ }^{8}$ Who owns them or is entitled to possession of them? Can they be bought and sold; stolen or bequeathed? Who can get access to them or to the information they encode? Does it depend on the purpose for which access is sought - for therapeutic reasons, for quality assurance, or for forensic testing to obtain evidence? Can stored body parts and tissue be used in research; or in research projects different from those for which they were first acquired? Whose consent is required? Who should share in the proceeds if a profitable discovery is made from research on them? Do the same rules apply to all types of stored human body parts and tissue? Should there be a different rule for tissue collected for diagnosis of familial genetic conditions, or for genetic registers established to assist families by indicating their genetic pedigree and assessing their risks for genetic

\footnotetext{
${ }^{7}$ Department of Health, Report of a census of organs and tissues retained by pathology services in England, 2001. This is available at http://www.doh.gov.uk/organcensus/census.pdf

${ }^{8}$ See my scenario in L Skene, "Legal issues related to the ownership of and access to bodily material" (2002) Trends in Molecular Medicine (in press); available at http://news.bmn.com/hmsbeagle.
} 
conditions? Is there adequate legal protection for people's privacy if they lose control over stored genetic material or information?

The answers to these questions are by no means clear in the present state of the law. There is legislation relevant to some aspects (such as the legislation on tissue donation and coronial investigations), and a few isolated cases. For the most part, however, the taking and use of human body parts and tissue is largely unregulated. Ultimately, the law seems to depend on the context in which questions concerning proprietary rights are asked and the purposes for which the body parts or tissue were first taken, retained and used. This is explained in the following sections of the paper that describe some of the legal principles that have been stated and the context in which that has occurred

\section{CASES ON CORPSES: THE $19^{\text {th }}$ CENTURY VIEW BASED ON RELIGION, PUBLIC HEALTH OR PUBLIC DECENCY}

In early English cases (mostly from the nineteenth century) and also in Australia, courts had to decide who was entitled to possession of the body of a deceased person. The principle was established that there is no property in a corpse ${ }^{9}$ and "neither a corpse, nor parts of a corpse... are property protected by rights". ${ }^{10}$ A corpse could therefore not be owned; nor could it be stolen. However, the personal representatives of the deceased were entitled to possession of the body for the purpose of burial and could obtain an order of mandamus to get the body back for burial if it was held by someone else. ${ }^{11}$

The context in which these early cases were decided was one of bodies and body parts. You could clearly see theses things and, even if this was not spelt out, they had special significance by reason of being "people" or parts of them. The possession of a corpse was also "injurious to the public welfare", based on "considerations of religion, or public health or public decency"12 or "indignities offered to human remains". ${ }^{13}$ The same principles were applied without further examination to body parts as well as to bodies. The issue of tissue samples (and a fortiori, encoded genetic information) had not yet arisen.

The "no property in a corpse" rule seems to be the same today, both in the United Kingdom and in Australia, despite the small number of cases on which it was based. In a recent Australian case, Calma $v$ Sesar, ${ }^{14}$ the parents of a deceased Aboriginal boy

\footnotetext{
${ }^{9}$ Doodeward v Spence (1908) 6 CLR 406 (HCA); Williams v Williams (1882) 20 Ch D 659.

${ }^{10} R v$ Kelly [1998] 3 All ER 741 at 749 (Rose LJ). This was subject to the rider "not in themselves and without more capable of being property" (ibid, emphasis added).

${ }^{11} R$ v Fox (1981) 2 QB 246. Others may have a right to possession of bodies or parts of bodies. A coroner may hold a body for a coronial inquiry until the inquiry is finished: $R v$ Bristol Coroner ex parte Kerr [1974] QB 652, Lord Widgery CJ at 659B. A person licensed to possess an "anatomical specimen” has a statutory right to possession under the Anatomy Act 1984 (UK) s 1(2)(a). Note that, although it has commonly been said that an executor has the right to possession of a body for burial, Professors Kennedy and Grubb suggest that it is more likely that the relevant person is the "person(s) next entitled to be appointed the admnistrator of the deceased's estate under the Non-Contentious Probate Rules 1987 (SI 1987 No 2024) r 22, ie the surviving spouse, children, parents siblings etc”: Ian Kennedy and Andrew Grubb, Medical Law, Butterworths, London ( $3^{\text {rd }}$ ed 2000) p 2243, citing P Matthews and J Freeman (eds) Jervis on Coroners (11 ${ }^{\text {th }}$ edn, 1993) at para 7-05.

${ }^{12}$ Doodeward v Spence, above $\mathrm{n} 9$.

${ }^{13}$ Foster v Dodd (1866) LQ 1 QB 475, (1867) LR 3 QB 67 (Byles J)

14 (1992) 106 FLR 446.
} 
were arguing about where he should be buried. The court said that the parents had equal rights to possession of the body for burial, but did not "own” the body.

Personal representatives have a right to possession of the body; property in the body does not vest in them. As Professor Lanham persuasively argued some years ago, "the person who has actual physical custody of the body has lawful possession (and the duty of disposal) of it until someone with a higher right (eg an executor or parent) claims the body; one reason is that the latter people cannot be in possession until they have animus possidendi". ${ }^{15}$ I shall return later in the paper to this important rider to the personal representatives’ right to possession.

At the same time as courts were saying that there could be no property in a corpse (or in parts of a corpse), a principle was developed that work and skill could give a corpse pecuniary value and make it property. ${ }^{16}$ In Doodeward $v$ Spence, ${ }^{17}$ the High Court of Australia held that what was described in the case as a "two-headed baby" could be property because of the "work and skill" expended in preserving it. The person who did the work, or exercised the skill, could therefore sue in trover or in detinue to require its return. The same principle applied to body parts removed from the body. ${ }^{18}$ In $R v$ Kelly, ${ }^{19}$ the Court of Appeal upheld the conviction for theft of an artist who removed body parts from the Royal College of Surgeons to draw them. ${ }^{20}$ Rose LJ said that "parts of a corpse are capable of being property within s 4 of the Theft Act, if they have acquired different attributes by virtue of the application of skill, such as dissection or preservation techniques, for exhibition or teaching purposes". ${ }^{21}$ Stored tissue (such as blood and blood products) has also been held to be property for some purposes. ${ }^{22}$ The meaning and implications of the "work and skill” principle are examined later in the paper.

\section{5. $20^{\text {th }}$ CENTURY AMERICA: PATENTS AND THE BIOTECHNOLOGY INDUSTRY}

In the American case, Moore $v$ Regents of the University of California ${ }^{23}$ the context of the decision was one of scientific research and the vitally important developing biotechnology industry. Mr Moore's physician, Dr David Golde, had removed Moore's enlarged spleen to delay the progress of his hairy cell leukemia. Without telling Moore, the doctor retained parts of the spleen for research and developed a valuable cell line that was later patented. The cell line contained Moore's DNA. He claimed a share of the proceeds. The Supreme Court of California held that Moore had no proprietary interest in the removed tissue and could not sue in conversion. ${ }^{24}$

\footnotetext{
${ }^{15}$ D Lanham “Transplants and the Human Tissue Act 1961” (1971) 11 Med Sci Law 16.

${ }^{16}$ Discussed by Kennedy and Grubb, n 11 above, 2000, 2244-2250.

17 Ibid .

${ }^{18}$ Kennedy and Grubb, above n 11 at 2244.

${ }^{19}$ Above $n$ 10..

${ }^{20}$ An employee of the College who removed the parts from the College was also convicted

${ }^{21}$ Kelly, above n 10.

${ }^{22} R$ v Rothery [1976] Crim L. R 691 (CA); PQ v Australian Red Cross Society [1992] 1 VR 19; discussed below.

${ }^{23} 793$ P 2d 479 Cal SC (1990).

${ }^{24}$ Note that conversion is "a tort that protects against interference with possessory and ownership interests in personal property” : id (Panelli J). Moore’s claim against Dr Golde and the University of
} 
The court said that the removal of tissue from the body extinguished the person's property interest in $\mathrm{it}^{25}$ that holding otherwise would restrict the emerging biotechnology industry; ${ }^{26}$ and that the grant of a patent showed the tissue could not belong to Moore. ${ }^{27}$

Before examining further the context of this decision, consider the significance of the outcome. A cell line consists of living cells that can be reproduced indefinitely. The cells are not fixed in a laboratory medium for observation or research. Although preserved in an artificial medium, each cell contains Mr Moore's DNA. Yet the court found that Mr Moore did not own them. Nor did he have a beneficial interest in them that would support an action in conversion. He could not get them back nor require that they must be destroyed.

Now, remember the context of the decision. It was specifically noted by the court. There had already been a large number of biological patents in the United States, including patents of cell lines. The "Mo cell line”, developed from Mr Moore's spleen cells, was simply one of them. Cell lines are one of the basic tools for microbiological research which in turn is essential if American scientists and the pharmaceutical industry are to take advantage of the discoveries of the human genome program. Imagine the consequences if the court had held that Moore owned or had proprietary rights in his cells, or even that he was entitled to share in the proceeds of their use in research! In the words of the majority judgment, "In effect, what Mr Moore is asking us to do is to impose a tort duty on scientists to investigate the consensual pedigree of each human cell used in research". ${ }^{28}$

\section{6. $20^{\text {th }}$ and $21^{\text {st }}$ CENTURY ENGLAND AND AUSTRALIA: TISSUE FOR FORENSIC PURPOSES}

In the late twentieth century, in a different context again, some courts moved away from the earlier English case law when confronted with new types of human tissue. The climate here is clinical and pragmatic. The subject matter is no longer bodies and body parts, but tissue preserved in laboratories. And the issue is who should have the right to control that tissue when access is sought for forensic purposes.

In Dobson $v$ North Tyneside Health Authority (NTHA), ${ }^{29}$ the administratrix of a deceased patient sued the NTHA for medical negligence, and also the Newcastle Health Authority for failing to preserve the patient's brain that was needed for

California had 13 causes of action, including conversion of bodily property, lack of informed consent, breach of fiduciary duty, fraud, unjust enrichment, and negligent misrepresentation.

${ }^{25}$ Moore, above n 23, at 488-89.

${ }^{26}$ Panelli $\mathrm{J}$ that thousands of cell lines exist in tissue repositories and that patent holders are required to make samples available to anyone. Scientists commonly use human tissue or cells in their research; and (quoting a report of the House Committee on Science and Technology of the United States Congress) approximately $25-30 \%$ of the nearly 350 commercial biotechnology firms in the US “appear[ed] to be engaged in research to develop a human therapeutic or diagnostic reagent ... Most, but not all, of the human therapeutic products are derived from human tissues and cells, or human cell-lines or cloned genes”. M Lin, 'Conferring a Federal Property Right in Genetic Material: Stepping into the Future with the Genetic Privacy' 1996(2) American Journal of Law and Medicine 109, 118.

${ }^{27}$ Moore, above n 23, 492-93.

${ }^{28}$ Moore, above n 23.

${ }^{29}$ [1997] 1 WLR 596. 
evidence. (The brain had been removed and fixed in paraffin but was later destroyed). The admistratrix relied on the principle established in earlier cases ${ }^{30}$ that personal representatives are entitled to possession of the corpse of a deceased person. The court held, however, that she was not entitled to possession of the brain as she had not been appointed administratix until after the body was buried and, by then the brain had almost certainly been destroyed. The court did not take the opportunity to re-examine the law relating to tissue or to declare any new principles.

That did, however, occur in the Australian case of Roche $v$ Douglas, ${ }^{31}$ albeit in the limited circumstances of a preliminary hearing. A Perth woman claimed a share in the estate of a deceased man she said was her father. In order to succeed, she had to prove paternity. The man had tissue removed during surgery and it was preserved in paraffin in a pathology laboratory. She applied for a court order requiring the tissue to be tested. Under the Court Rules, a Master of the Supreme Court could make an order granting access to "property" for a test. The issue was therefore whether the stored tissue was property, so that an order could be made. The Master said it was property by its very nature, not by virtue of "work" done on it and he ordered that the test be done. However, he said that "it [was] not necessary for [him] to determine who holds the proprietary interest in the tissue", that is, who "owns it".

Although only a preliminary hearing, this decision is significant. First, the Master recognised that the issue raised by the case was novel. He expressly described it as "the first time an application has been made allowing for testing of tissue held by a laboratory"; 32 and "the first case in the $21^{\text {st }}$ century on the status of human tissue" ${ }^{33}$ Secondly, the Master discussed in the judgment many earlier cases on the legal status of human tissue removed from the body, together with academic commentary. He specifically distinguished the case before the court from the earlier common law that had rejected the principle that there could be property in tissue removed from the body. He also distinguished it from Doodeward $v$ Spence $^{34}$ which he said was "of interest" but "not directly relevant" and, in any event, "it was decided in 1908 - some 50 years before Watson and Crick described the DNA double helix". ${ }^{35}$ Thirdly, the reasons given in Roche for regarding tissue as property seem logical: "To deny that the tissue samples are property, in contrast to the paraffin in which the samples are kept or the jar in which both the paraffin and the samples are stored, would be ... a legal fiction". ${ }^{36}$

It is therefore tempting to regard Roche as authority for the proposition that, in Australian law, stored tissue is property. However, one must bear in mind its limitations as a precedent, both legal and contextual. The Master was asked to make a preliminary ruling that tissue should be tested in order to enable the plaintiff to prove one element of her case. This ruling had no immediate legal implications for the parties. It enabled the principal legal argument to be deferred until after the test had been conducted. If the test could be done, "[t]here will be a considerable saving in

\footnotetext{
${ }^{30}$ Such as Doodeward, above n 9.

${ }^{31}$ [2000] WASC 146 (WASC).

${ }^{32}$ Id, para 22.

${ }^{33}$ Id, para 14.

${ }^{34}$ Above n 6.

${ }^{35}$ Above n 31, para 14.

${ }^{36}$ Id, para 24.
} 
time and costs, so on the particular facts of this case there is a compelling reason for holding the tissue samples to be property". ${ }^{37}$ In other words, reason and common sense supported such a decision in that case.

Even more importantly, however, the context in which the status of stored tissue was considered in Roche was not one of ownership. It was access. If the tissue is property and so capable of ownership, who owns it, or has a proprietary interest in it? The court in Roche was able to make the order for testing without deciding this question. ${ }^{38}$ Similarly, the English court in Dobson ${ }^{39}$ was able to reach its decision that the administratrix was not entitled to possession of the stored tissue on the narrow ground that she had not been appointed before it was destroyed and so could not be entitled to possession. The court did not have to decide whether the tissue was property and did not comment on that issue. ${ }^{40}$

Other more recent cases have also held that human tissue is property, again for reasons that seem pragmatic. In $R v$ Rothery, ${ }^{41}$ a defendant who removed a blood sample after a blood alcohol test was found guilty of theft. ${ }^{42}$ In PQ $v$ Australian Red Cross Society ${ }^{43}$ the Supreme Court of Victoria accepted that blood products were goods under the Trade Practices Act $1974 .^{44}$

\section{7. $21^{\text {st }}$ CENTURY: BRISTOL \& ALDER HEY - STORED BODIES AND BODY PARTS}

Other claims in relation to human body parts and tissue have recently attracted attention in the United Kingdom. These relate particularly to foetal and other body parts and tissue held after still-births and terminations of pregnancy by the Bristol Infirmary, the Alder Hey Hospital, Merseyside and other hospitals in the late 1980s and early 1990s for post mortem examinations. The concern about this issue has been so great that there have been a number of inquiries, in particular the Bristol Inquiry, the Alder Hey Inquiry and the McLean Inquiry. Before turning to the findings and recommendations of these inquiries, however, we should pause and consider the climate in which they were undertaken.

This was not a situation in which people sought access to their tissue preserved on slides or in paraffin wax. The issue here was whole bodies, organs and other body parts. The people whose concerns led to the inquiries were parents of children who died in hospital in questionable circumstances. The parents are justifiably angry because of the way their children died and because they were not consulted about their children's organs

\footnotetext{
${ }^{37}$ Id, para 23.

${ }^{38}$ Id, para 25. The order was made against the pathology laboratory because it was in possession of the tissue: ibid.

${ }^{39}$ Above n 29.

${ }^{40}$ The claim in bailment was.not fully discussed because, even if there had been a bailment, it would have been by the doctor, not by the administratrix.

${ }^{41}$ [1976] Crim L. R 691 (CA); see also R v Welsh [1974] RTR 478 (CA): urine held to be "property” and capable of being stolen.

${ }^{42}$ Cf Kelly, above n 10.

${ }^{43}$ [1992] 1 VR 19.

${ }^{44}$ Similarly in the UK, a commercial agreement for the sale of tissue that falls outside the Organ Transplants Act 1989 would be governed by the Supply of Goods and Services Act 1982, if the supplier "acts in the course of a business": Kennedy and Grubb, above, n 11 at 1780.
} 
being retained for post-mortem examination and research. A spokesman for the group representing the parents of the Alder Hey babies, Pity $2,{ }^{45}$ is reported to have said "Some of these foetuses are from stillbirths and miscarriages, which means they were wanted and I'm sure parents would have no idea they would end up in a hospital store". ${ }^{46}$ Another parent is reported to have said, in a similar case involving a Birmingham hospital, that she commenced the legal proceedings to expose the hospital's "arrogance” in removing her daughter's organs without her consent. ${ }^{47}$

Not surprisingly, the grief and anger of these parents struck a national chord and the newspapers took up their cause, both in relation to Bristol and then to Alder Hey. In The Times, a journalist reported that the Home Secretary, Alan Milburn, had said that the report on organ retention at Alder Hey Hospital was "the most shocking he [had] read"; that "[o]ne incident given in the report is believed to concern the discovery of a child's head stored in a jar"; and that "thymus glands taken from living children during heart operations [were given] to a drug company for research, in exchange for financial donations". ${ }^{48}$ The President of the British Paediatric Cardiac Association wrote, in a letter to The Times, that he had learnt only during the Bristol Inquiry that "organs had been retained without the full knowledge of the parents ...or subsequent to removal during autopsies ordered by the Coroner" and that "loss of public trust was inevitable". ${ }^{49}$ The reports themselves showed clearly that the inquiries were conducted in such a climate.

When the Bristol Inquiry released its interim report on the removal and retention of human material, it understandably wanted to meet the very real concerns of the Bristol parents. ${ }^{50}$ Their children had died in circumstances that are still under investigation. Several of the doctors undertaking paediatric cardiac surgery at the hospital had been subject to a disciplinary inquiry and two suspended from practice. Civil claims had been made against the hospital alleging negligence and substantial damages already

\footnotetext{
${ }^{45}$ PITY 2 is an acronym for "parents who inter their young twice”. The group was instrumental in having the law changed so that organs could be cremated (previously only bodies could be cremated): Statutory Instrument 2000, no 58.

${ }^{46}$ David Charter, "Hospital in organs scandal holds 400 foetuses”, The Times, 14 November 2000.

${ }^{47}$ Ibid. The Bristol Report also used the word "arrogance”: para 32.

${ }^{48}$ Joanna Bale, “New laws will stop ‘shocking' organ removal”, The Times, 29 Jan 2001, p 6. A frontpage report in The Times on 31 Jan 2001 (by Nigel Hawkins and Russell Jenkins) was headed "Hospitals braced for anger over 100,000 stored organs" and reported doctors "systematically stripping organs" . Both this report and another in The Times on 27 Jan 2001 used the words "outrage", "scandal” and "horror": Ian Cobain, Russell Jenkins, Adam Sage, "Hospitals sold tissue of living children”: p 12. On 31 Jan 2001, Nigel Hawkes reported on the findings of the Alder Hey Report: "a system riddled with complacency and neglect" and a documentation system that was "shocking and disrespectful" at Alder Hey hospital; the university's "managerial inadequacy"; the coroner's "slack procedures": "Retention of organs illegal and unethical”, p 8. An editorial in The Times on 5 Feb 2001 referred to "medical practices that have, at times, been haughty and haphazard" and "[a]rrogance within the medical profession towards relatives of the dead": "Some summit, Milburn, media and medicine for the living”.

${ }^{49}$ Robert H Anderson, The Times, 7 Feb 2001, p 19.

50 The report does not hold back in acknowledging the feelings of the parents: "Parents, particularly those of children who have died in hospital, have been shocked". Parents were "almost entirely unaware of this practice by pathologists" and even if they had consented to autopsies in hospital, they did not have "any real understanding of what was involved": p 1. See also para 94: parents did not understand the meaning of tissue, that tissue might be retained, perhaps indefinitely, that tissue could be put to a variety of uses and, that as a consequence, they would be burying or cremating their child's body incomplete.
} 
awarded. Many parents were not consulted about their children's body parts being retained after autopsy; and, even when they consented to a hospital autopsy, they often did not understand what they were consenting to. The inquiry was undertaken at "a time of failing trust". ${ }^{51}$ All of these matters must be borne in mind when reading the report.

For the purposes of the present paper, there are three main points to be made about the Bristol Report. First, it emphasised the need to inform and involve parents. ${ }^{52}$ It recommended that parents should be informed and their consent sought, not only for a hospital post-mortem, ${ }^{53}$ where the law does not allow a post-mortem if a relative objects, but also for a coronial post-mortem, ${ }^{54}$ which can lawfully be done without consulting parents. The report contains detailed recommendations concerning the information and support that should be provided to parents. ${ }^{55}$

Secondly, although the report states that "[t]he law regulating the removal, retention, use and disposal of human material is obscure, uncertain and arcane", ${ }^{56}$ it emphasised that the law was outside its terms of reference. ${ }^{57}$ Thirdly, there are nevertheless many statements in the Report that are relevant to property and control issues. The report concluded, for example, that after both hospital and coronial post-mortems, pathologists have no legal authority to retain body parts or tissue when the postmortem has been completed, despite the "long-standing habit" of pathologists of keeping them for research and education. ${ }^{58}$ Even when the law allows a post-mortem without parental knowledge, or in the face of objections from relatives, the Coroner is functus officio after the inquest is concluded and the verdict returned. ${ }^{59}$ The pathologist, as the Coroner's agent, no longer has authority to hold the body or anything removed from it; ${ }^{60}$ and must "cede lawful possession to the parents if requested to do so". ${ }^{61}$ The parents are entitled to possession but solely for the purpose

\footnotetext{
${ }^{51}$ Bristol Report, n 1 above, para 114.

52 The Report referred to the "informed co-operation” of parents (para 126, rec 2) and recognised parents' implicit right of control. There are also recommendations on the need to support parents in making decisions at times of stress: appropriate privacy, support, counselling (rec 35); time to reflect (rec 43).

${ }^{53}$ Hospital post-mortems are undertaken at the request of clinicians or parents to assist in understanding the cause of death and to learn for future care (para 28). This type of post-mortem cannot be lawfully undertaken if a relative objects (para 17, Annex B paras 72-79, 154-161; this may be a quite distant relative: ibid, paras 90-92; Human Tissue Act $1961 \mathrm{~s} 2$ 2(2); the guidelines in The Autopsy and Audit use the language of consent: Annex B paras 80, 113).

${ }^{54}$ Coronial post-mortems are authorised by the Coroner's Act 1989 ss 8,9,20. Their purpose is to determine the cause of death and, if necessary, the identity of deceased. The Coroner is not required to seek consent or to respect the objections of the parents but the "Practice Notes for Coroners" recommend that relatives and family be informed about the post-mortem: Annex B, paras 43,45.

${ }^{55}$ For a Coroner's post-mortem, the Report recommends that the Coroner should contact parents who object and explain why an autopsy is necessary (Rec 9). Parents should be told about the post-mortem - date, time and place (Recm 14); timing of burial or cremation (Rec 17, 39); (on being asked for consent to retain human material) that human material includes organs, parts of organs and tissue in various forms (Rec 24); the purpose for which tissue is kept - audit, education, research, display (eg at a conference) or archiving (Rec 25). Parents should have time for reflection (Recm 26). There are similar recommendations for hospital autopsies.

${ }^{56}$ Bristol Report, $\mathrm{n} 1$ above, p 1.

${ }^{57}$ Id, paras 129, 191.

${ }^{58}$ Id, para 27.

${ }^{59}$ Id, Annex B paras 38, 55-58, 141, 145.

${ }^{60}$ Id, para .

${ }^{61}$ Id, para 75.
} 
of burial or cremation. ${ }^{62}$ For the pathologist or hospital to be entitled to retain human material, it would be necessary to distinguish on the basis of "whether the human material has been worked on and in consequence has acquired different attributes. ${ }^{63}$ ... [and] the legal position should not rest on such arcane distinctions. Furthermore, if this is the law, its ignoring of the need to have regard to and respect the views of parents makes it unacceptable". ${ }^{64}$

Now, returning to the context in which the inquiry was conducted, one can see that this was vitally relevant to its conclusions and recommendations. This is evident throughout the Report. Take the term "human material” that the Committee used to include "organs and tissue; also amputated limbs". When defined in this way, it is not surprising that "[p]arents regard human material as part of the child" even if "pathologists and clinicians [regard it] as a specimen or object". ${ }^{5}$ The recommendations then logically follow not only that parents should be informed about the post-mortem and offered support, but also that they should be entitled to have the body and body parts returned to them for burial or cremation if they wish. If the "human material" in a given case had been solely a tissue sample preserved on a slide, the argument seems not only less cogent, but even absurd. (I take up the longterm practical effects of such a principle in the next section of the paper.) However much one can see the reasons for talking about "human material" in the context of the Bristol Inquiry, this is danger in eliding bodies, body parts and tissue when considering these issues.

The climate that influenced the Bristol Inquiry was equally evident in the later reports and government publications on retained organs. The guidelines of the Government's Chief Medical Officer (CMO) on post-mortem examination advise that spouses or relatives should be given clear written information about "the options for the disposal of organs body parts and tissues retained at post-mortem, including arrangements for reuniting these with the body before the funeral". ${ }^{66}$ The Department of Health's Census of Organs and Tissues retained by Pathology Services, ${ }^{67}$ which was published at the same time as the report on Alder Hey (see below), reached conclusions similar to the Bristol Inquiry - many organs and tissue were retained after postmortems, ${ }^{68}$ with tissue being retained in a much higher percentage of post-mortems on infants and children; ${ }^{69}$ sometimes without consent and, if there was consent, without the relatives understanding what was involved, especially that "whole organs might be retained under the aegis of 'tissue," ${ }^{70}$ Many of the retained organs and tissue came from

\footnotetext{
${ }^{62}$ Rec 60. See too Report, Annex B para 66: the parents have "a right to possession attendant upon a duty to dispose”. If they do not exercise this right the pathologist has power to dispose of it but no duty to do so: ibid.

${ }^{63}$ Cf Doodeward $v$ Spence, above n 9, to which the report refers: para 78, note 60.

${ }^{64}$ Bristol Report, n 1 above, para 78. The comment that "the legal position should not rest on such arcane distinctions" was described as a "remark in passing” but that does not necessarily undermine its weight.

${ }^{65}$ Id, para 33.

${ }^{66}$ Organ Retention: Interim Guidance on Post-Mortem Examination (5 Jan 2001) para 4 (emphasis added)

${ }^{67}$ Above $n 7$.

${ }^{68}$ The percentage where organs were retained in 1999 was $2.3 \%$; the percentage where tissue was retained was $42 \%$ : id p 2.

${ }^{69}$ Tissue was retained from $65 \%$ of post-mortems on children, $72 \%$ of post-mortems on infants (under 1 year) or stillborn babies, and 39\% of post-mortems on adults: id p 2.

${ }^{70}$ Id $\mathrm{p} 3$.
} 
coroners' post-mortems, sometimes being retained without consent on the basis of "tradition" or the pathologist's discretion. ${ }^{71}$ After the retention period, organs and tissue were generally "disposed of as clinical waste", though organs and body parts were sometimes returned to parents for burial or cremation. ${ }^{72}$ The Donaldson Report $^{73}$ reached similar conclusions, commenting on the unsatisfactory nature of the agreement forms, the lack of information and the lack of counselling support or advice when a signature was being sought at a distressing time which suggests that in many cases, agreement to retention fell well short of being fully informed consent.

The Alder Hey Report was in similar vein. It made many adverse findings, particularly concerning the conduct of pathologist Professor Van Velzen (it recommended that he should never be permitted to practise again); and the hospital management. The report stated that, for post-mortem examination of children, "fully informed consent is required and nothing less" on the "application of basic principles of respect for the person, their welfare and their wishes". ${ }^{74}$ Fully informed consent requires "all the information required to form a final decision ... no matter how distasteful the giving of this information might be to the clinician concerned". ${ }^{75}$ The report also recommended that the next of kin should have the right to give instructions for "final disposal of organs or tissue". ${ }^{76}$ However, in one important respect, the recommendations of the Alder Hey Report differed from the Bristol Report. It said:

Once the consent form is signed we favour the next of kin relinquishing further control ... subject to the next of kin having the right to specify how ...the material should be disposed of respectfully. ... A more liberal attitude should be considered with regard to the retention and use of tissue, particularly in the form of wax blocks and slides. These are of invaluable benefit for research and teaching. They may also be an important resource for families who may seek access to archived material for the benefit of their family and future generations.... Once fully informed consent has been obtained for [tissue] retention and use, the hospital's undertaking to use it and to dispose of the remainder should be enough. Were it otherwise we would have a situation where clinicians/researchers/teachers would [have to make] repeated requests to parents for additional consent ... The consent to retain tissue should be general, to permit use within ethically approved research projects ... ${ }^{77}$

\footnotetext{
${ }^{71}$ Id p 4. Other authorisation was consent from relatives; research usually with consent; and medicolegal use: ibid.

${ }^{72}$ Id p 4. Foetuses and stillborn babies were generally treated more sensitively; they were often stored separately and parents consulted before disposal: id pp 4-5.

${ }^{73}$ The Report of the Chief Medical Officer, the Donaldson Report on the Royal Liverpool Children's NHS Trust.

${ }^{74}$ Alder Hey Report, n 4 above, ch 11, para 1.1 Like the Bristol Report, the Alder Hey Report recommended that consent should be sought for coronial post mortems as well as for hospital postmortems.

${ }^{75}$ Id, ch 11, para 1.3. Communication should be sensitive, open and detailed (ch 11, para 1.6); effective and sympathetic (ch 11, para 1.7); with “[c]lear informal language” (ch 11, para 2.3); "respecting individual attitudes to the body following death" (ch 11 para 4.8). See also Ch 12, bereavement advice; and ch 12, para 1.12: “The need for respect cannot be overstated".

${ }^{76} \mathrm{Id}$, ch 11, para 3.2; the report said that this principle applied also to tissue in archives throughout the country that was previosuly taken unlawfully: ch 11, para 1.9. See also proposed consent form: ch 11 para 4, especially para 4.8

${ }^{77}$ Id, ch 11, paras 3.3, 3.4 (emphasis added).
} 
This is significant first, in suggesting that tissue should be distinguished from bodies and body parts; but even more, in its theoretical basis. The emphasis, as elsewhere in the report, is on the right of the next of kin to be informed and to decide - a personal right; not on a right of continued control - a proprietary right. Also, account is taken of the long-term implications for research and teaching if the next of kin have ongoing rights in respect of the retained tissue (as in Moore above). The reference to "ethically approved research projects" reminds us of another context in which principles have been developed in relation to the use of retained tissue in research. These also emphasise the need to inform people and obtain consent but the protection later is through ethics committees, not proprietary rights or continued control. ${ }^{78}$

\section{THE WAY FORWARD: RESOLVING THE CONFLICTS}

Let us now consider the principles that should be adopted in the future development of the law in relation to possession, use and control of excised human body parts and tissue, taking account of the diverse views in the cases and inquiries. We need principles that will answer in a coherent structure the questions raised throughout this paper. May I remind you first of these questions, then suggest what I think the answers should be, irrespective of the current law. Finally, I discuss alternatives for developing the law to reach the "right" answers for the various types of stored body parts and tissue, concluding with my own recommendations.

\section{A. Right to possession for burial or cremation of deceased person}

First, consider the questions and the "right" answers. Should the next of kin of people who have died be legally entitled to possession of the body of their deceased relative for burial or cremation? Similarly, should parents of children who have died in hospital be legally entitled to possession of their child's body and body parts after a post-mortem for burial or cremation? The answer is clearly yes, on grounds of emotion, respect for people's religious and cultural beliefs, and hygiene. ${ }^{79}$ However, when one asks whether they should also be entitled to retrieve tissue samples on slides for burial or cremation, the answer is surely no. ${ }^{80}$ The moral significance attached to bodies and parts of bodies is different from that attached to tissue samples. This is the case whatever the religious or cultural background of those concerned.

\section{B. Rights where body parts or tissue of a deceased person are to be used for purposes other than burial or cremation}

If a person has died and the body parts or tissue are not wanted for burial or cremation but for other purposes, should the wishes of the deceased before death - or the next of kin after death - be taken into account? Should their consent be required before the excised body parts or tissue are used for therapeutic purposes or in research? The answer is generally yes - or at least that the use should not occur in face of the

\footnotetext{
${ }^{78}$ Eg Royal College of Pathologists (UK), Guidelines for the Retention of Tissues and Organs at PostMortem Examination, March 2000; Australian National Statement on Ethical Conduct in Research Involving Humans, 1999; available at http://www.health.gov.au/nhmrc/publications/pdf/e35.pdf.

${ }^{79}$ See above discussion of Bristol and Alder Hey Reports..

${ }^{80}$ Cf Alder Hey Report, above n 77 and passage quoted in text.
} 
known objection from the deceased or relatives. ${ }^{81}$ Reasons include respect for people's autonomy and their human rights, ${ }^{82}$ such as their right to make their own decisions about what may be done to their body after death as during life; and also promotion of research and teaching by not alienating community good will with coercion or subterfuge.

But what if the deceased or the relatives seek to impose conditions on their consent? ${ }^{83}$ Should that be allowed and should those conditions be binding? Should relatives be entitled to withdraw their consent and require the retained body parts or tissue later to be returned to them for burial or cremation, or otherwise disposed of? Should they be permitted to sell (or to give away) parts of the body before it is disposed of? They might, for example, remove a strand of hair from the deceased as a memento; or sell the full tresses to a wigmaker. Similarly, the deceased might attempt before death to authorise the removal and disposition of his or her hair.

In answering these questions, I believe that a distinction should be made between two types of rights. The first are personal rights. They protect a person's autonomy, or the right to self-determination. These rights reflect our intuitive feeling that one's body is in some way one's own - subject to one's own control. The law of battery - and the principle of informed consent in negligence - protect one's right to bodily integrity during life and reflect a similar value. ${ }^{84}$ The right to be consulted about the use of one's body or body parts - and to refuse or to impose conditions - is a right of this kind. In contrast, any right of control or disposition one has, after the initial consent, is a proprietary right (a right of ownership or ongoing control). In my view, such a right should not be recognised on the part of the person whose body, body parts or tissue are in question, in relation to a corpse, or excised body parts or tissue removed after death, or during life. ${ }^{85}$

\footnotetext{
81 “About 1 in 4 families object to their relatives’ organs being donated”: Department of Health (DOH), An investigation into conditional organ donation, Report of the Panel, para 3.20. The need for information and consent was emphasised by the Bristol Inquiry (nn 51-53 above and accompanying text); the CMO guidelines (above n 66 and text); the Donaldson Report (above n 73 and text); and the Alder Hey Report (above nn 74-77 and text). Professor Ken Mason and Dr Graeme Laurie argue, on the other hand, that argue that only the consent (or refusal) of the deceased should be considered, not that of relatives, as the "autonomy" in question is that of the deceased: JK Mason and GT Laurie, "Consent or property? Dealing with the body and its parts in the shadow of Bristol and Alder Hey" (2001) Mod Law Rev 710-729.

${ }^{82}$ Bristol Report, n 1 above, para 172 - acts potentially incompatible with Art 8 European Convention on Human Rights and Fundamental Freedoms (family life); para 174 Patients Charter - rights to care in NHS, to information; to choose whether to participate in research (para 176-180); right to respect for religion, cultural views. Also European Convention on Human Rights and Biomedicine Art 2: "The rights and welfare of the human being shall prevail over the sole interest of society or science”. Art 5: "free and informed consent".

${ }^{83}$ Examples of such conditions are a white recipient (DOH Report, above $\mathrm{n}$ 81); use only for research of a particular type, eg diabetes research, not others, eg research on contraception. The DOH Report (above $\mathrm{n}$ 81) bans the first condition (race), but would seem to allow the others (it allows directions on what organs may be taken (para 1.9) but says nothing further about uses for research. The Human Fertilisation and Embryology Act 1990 (UK) allows some conditions to be imposed but is based on consent and not property.

${ }^{84}$ Also, in the United States, the law on fiduciary obligations protects these interests: Moore above $\mathrm{n}$ 23.

${ }^{85} \mathrm{Cf}$ the similar distinction between personal and proprietary rights made in the Alder Hey Report: above $\mathrm{n} 82$ and text quoted from Report.
} 
This is a contentious view. ${ }^{86}$ Let me give some reasons for my rejection of a general principle that people should have a property interest, or a right of ongoing control, in their own bodies, body parts and tissue. Such a principle will sometimes be inconsistent with other legal principles recognising property interests in favour of others, such as the personal representatives' right to possession of a body for burial; and the rights of patent-holders and their successors in respect of patented biological inventions. ${ }^{87}$ There is an emotional repugnance at people selling ${ }^{88}$ their bodies and body parts. Stored genetic material should be available to blood relatives for their own testing, not subject to veto by one person. ${ }^{89}$ And it would unduly fetter teaching, research, commercialisation of biological inventions and the maintenance of museum collections. ${ }^{90}$ It would be possible for these activities still to be conducted if people had property rights in their bodies and body parts. But a better means of establishing extensive pathology collections, ${ }^{91}$ secure from later claims for the return of retained material, is a principle that hospitals and researchers have property interests in it and not the people from whom the material came. ${ }^{92}$ If consent is always required to hold tissue, collections may be less comprehensive and therefore less useful.

Thus, I propose that people should have a personal "autonomy" right to permit their bodies and their excised body parts or tissue to be used for teaching, or for therapeutic, medical or scientific research - or to prohibit such use - but they should have no proprietary right thereafter. ${ }^{93}$ If "conditions" are to be permitted on the use of retained or stored bodies or body parts, they might be imposed on the initial consent. An example is a requirement for payment. This could be met in two ways. One could allow this as a personal right, so that, if payment is not made, the only form of redress is an action for damages; there would be no right in relation to the retained tissue or to any product manufactured from it. Alternatively, one might prohibit payment on public policy grounds.

Other issues arise with dispositions of people's hair. To be consistent, the right to consent to removal and disposition should be the same if it is removed from the body after death at the person's direction during life. The donee or purchaser would then

\footnotetext{
${ }^{86}$ Many academic writers believe the opposite: Derek Morgan "Where do I own my body (and why?)" in Issues in Medical Law and Ethics, Cavendish, London, 2001, pp 83-104; JW Harris, Property and Justice, Clarendon Press, Oxford, 1996 (Harris states categorically at p 351: "Every person ought to be regarded as the owner of any separated part of his body”; Mason and Laurie, above n 81.

${ }^{87}$ There will be an inconsistency if the person has full ownership; lesser property interests can co-exist.

${ }^{88}$ Cf Harris, above n 86, at p 352: organs should not be commodified because that involves "an affront to our fundamental notions of human dignity”. Sale and property need not go together. One can have property interests that fall short of a "commercial" interest; see for example, the "mere-property useprivileges and control-powers": Harris, p 356. Nevertheless, in the public mind, property and sale are associated and that influences the popular response.

${ }^{89}$ See Loane Skene, "Patients' rights or family responsibilities? Two approaches to genetic testing” (1998) 6 Medical Law Review 1; Loane Skene, "Genetic Secrets and the Family: A Response to Bell and Bennett” ”(2001) 9 Medical Law Review 162.

${ }^{90}$ Some say that recognising people's property interests in their own bodies and its parts would in fact encourage research, eg by financial inducement to participate. See, eg, Derek Morgan, above n 86, p 99, references cited in his notes 67-70.

${ }^{91}$ Ideally, all types of tissue, and all types of illness or disease, should be represented, for purpose of comparison of symptoms, progression, effectiveness of intervention etc.

${ }^{92}$ This principle would apply as much to bodies and body parts as to tissue, though with bodies and body parts, the deceased or next of kin might retain a right to direct ultimate disposition. This right arises only if the personal representatives seek possession, see Lanham, text to note 15 above.

${ }^{93}$ Cf Alder Hey Report quoted in text to n 82 above.
} 
commit no offence in removing it and would gain a proprietary right in it, which should override the executor's right to possession of the body for burial. On the other hand, if the hair is taken without consent, that should be an offence. Moreover, the removal would be subject to liability for offences against public decency, desecration of a corpse and the like. Public health considerations should also prevent people bequeathing a whole body after death, other than for use in research and teaching under the relevant legislation. Bodies must be buried, cremated or hygienically preserved for anatomical purposes.

Note that many of these propositions rest on the assumption that bodies, body parts and tissue can be property and the subject of proprietary rights. Clearly, there will be legal restrictions on the uses that may be made of them. Institutions and their employees will be expected to treat human bodies, body parts and tissue respectfully and to use them only for scientific purposes. They will be expected to comply with the guidelines and monitoring procedures prescribed for medical and scientific research involving humans and to obtain approval from ethics committees for specific projects; especially in relation to maintaining confidentiality. But restrictions on the right to enjoy one's property to the full are commonplace, ${ }^{94}$ especially with real property. Governments acquire privately owned land for road-widening schemes, redevelopment and other purposes; heritage plans limit housing changes. Moreover, despite concerns about infringement of privacy when tissue is stored in laboratories, there is little indication that this has ever occurred when tissue or personal information has been obtained during an academic research project. Although the Bristol and Alder Hey Inquiries deployed practices at those hospitals, there was no allegation that people's confidential information had been wrongfully revealed. ${ }^{95}$

Note also the legal implications of recognising proprietary rights of a hospital or research institute in retained body parts or tissue where the person has given express or implied consent for their removal, retention and use. The proprietary right will enable the hospital to sell or donate the body parts and tissue for health care or research; ${ }^{96}$ or to dispose of them when they are no longer required. If these items are stolen, the thief may be charged with theft. ${ }^{97}$ If they are destroyed, the hospital may claim on its contents insurance.

\section{Body parts or tissue removed from a person who has not died, with the person's consent}

When body parts or tissue are removed from a person who has not died, different issues arise. Consider first removal with the person's consent. Should a person whose limb has been amputated for therapeutic reasons be permitted to require its return? ${ }^{98}$ Should a newly delivered woman be entitled to take home the placenta; or a woman

\footnotetext{
${ }^{94}$ See Andrew Grubb , “I, Me, Mine: Bodies, Parts and Property” (1998) Med Law International 299: people's right to use a thing in their possession may be limited by law - eg their ability to sell or even dispose of it.

${ }^{95}$ I suggest methods for promoting confidentiality in Loane Skene, " Ownership of human tissue and the law" (2002) Nature Reviews Genetics www.nature.com/reviews (in press).

${ }^{96}$ This fits in with the case law on sale of blood products: above nn 22, 44 above and text.

${ }^{97}$ Above nn 20, 21 and 42 and text.

${ }^{98}$ Cf letter by John Byfield to The Times, 12 Feb 2001 (p 17): "I very much doubt whether any hospital has ever involved a patient in the disposal of an amputated gangrenous leg or even a heart which has been replaced by a transplant”.
} 
who has miscarried, her aborted foetus ${ }^{99}$ Does the same principle apply to tissue on slides? Is there a distinction between body parts and tresses of hair, which are commonly sold; and, if so how should it be defined? What difference does it make if a body part (such as an organ) or tissue is removed for donation, rather than for therapeutic reasons; or if tissue ${ }^{100}$ is to be donated for use in research?

In the case of limbs, organs, foetuses and even tissue on slides, there are public health reasons why they should be promptly disposed of, properly preserved in a laboratory, or kept hygienically until needed for transplant. In each case, the disposal, retention or care should be the responsibility of the hospital or laboratory. The people from whom the body parts came should not have a legal right to get them back. This situation is different from returning parts of a corpse for burial or cremation where the religious or cultural expectations of many people require that body parts, as well as the body, should be disposed of with appropriate ceremony. People do not expect that body parts and tissue removed for therapeutic purposes should be returned to them and many people would object to such a practice. If a request is made for return of excised items, a hospital may exercise a discretion to return them if it is satisfied that there is no risk to public safety. ${ }^{101}$ But people should not have a proprietary right that requires excised body parts or tissue to be returned to them.

On the other hand, one might say that the expectation when body parts and tissue are removed for therapeutic purposes is that they should then be hygienically disposed of, for example by incineration. ${ }^{102}$ If that is not the case and hospital staff propose to use retained tissue for other purposes, the person concerned should have the same personal autonomy right to be informed and to refuse as he or she would have if the tissue were to be retained and used after the person's death. A limited exception might be made for the retention and use of tissue for purposes related to the treatment of the patient, on the basis of the patient's implied consent. That would justify holding tissue for re-testing, for example if new tests became available; or for medical audit. It might also extend to the use of retained tissue for teaching staff to diagnose and treat the patient's condition since the patient might benefit from improved skills and techniques when next admitted. An implied consent would not, however, authorise the retention and use of tissue if there were no perceived benefits for the patient. Also, consent could not be implied if a person specifically refused. If a person directed that his or her body parts or tissue should be destroyed, the hospital would not be lawfully entitled to retain them except for the patient's own care. ${ }^{103}$

\footnotetext{
${ }^{99}$ For the purposes of this paper, I do not discuss the special ethical and legal issues associated with foetuses, gametes and embryos.

${ }^{100}$ Only regenerative tissue may lawfully be donated for research. Organs may be donated for transplant but not for research.

${ }^{101}$ Examples are chemically preserved excised tonsils and kidney stones that are sometimes offered to patients to take home after surgery. The Nuffield Council on Bioethics also envisages that hospitals may return a patient's appendix or gallstone: Human Tissue, Ethical and Legal Issues, 1985, para 9.5, 102 See my arguments concerning discarded teeth: Skene, above n 95.

103 The reason is that the hospital would then have no legal authority to retain the tissue. An exception would arise if there were lawful authority other than consent, such as a statutory requirement or a court order. It would follow that Guthrie cards would have to be returned on request but not blood alcohol samples. If the hospital wanted to retain surgically removed body parts or tissue for forensic purposes (eg to use in evidence in litigation against it), it would need to obtain court authority to do so.
} 
Thus the general principles I propose are similar, whether body parts or tissue are removed from a deceased or living person. The person, or the personal representatives of a deceased person, should have a right to be consulted, to impose conditions and to refuse (with a limited exception for implied consent) but they should not have a proprietary right in relation to body parts and tissue removed with their consent. The person or institution holding the body parts or tissue should have a proprietary right over them, but it should be subject to an obligation to use them for medical or scientific purposes and to observe proper ethical standards. A breach of these requirements should be actionable by the person from whom the body part or tissue came, to recover damages ${ }^{104}$ (which should include punitive damages if indicated).

There seems, however, a theroetical problem with tresses of hair, where I see no reason why people should be prevented from buying, selling and owning them. One might perhaps make an exception on the ground that hair (and also fingernail clippings) are not living tissue; or that their removal and handling does not present the health risks presented by other bodily materials. Or one might make a more extensive exception for tissue sold outside the surgical context (ie when it is removed during therapeutic surgery not associated with organ or tissue donation). If I can sell my hair, why should I not be permitted to sell my blood or gametes (which is permitted in the United States)? What grounds could be suggested for prohibiting a person's right to sell their body parts or tissue removed in a hospital, yet allowing them to sell these things outside the hospital?

The answer to the last question in the United Kingdom and in Australia is at the heart of the policy underlying the legislation on tissue transplants. Donations are voluntary. Sale of organs and tissue is expressly prohibited. The reason is to protect potential donors from exploitation and to secure the healthiest organs and tissue for donation. Since people are not injured by cutting their hair and there is not the same need for quality control to protect recipients (or public health) as with organ and tissue donation, the selling of hair might be regarded as sui generis and the subject of separate regulation.

The law on the donation of organs or tissue should remain as it is. These should not be removed for donation or research without the donor (or the next of kin after death) being fully informed and their consent obtained (or the organ or tissue should not be used in the face of a known objection). This protects their personal autonomy rights. As with other types of tissue, the hospital should gain a proprietary right in the removed organs and tissue provided consent was given (or no objection known to exist) and they are lawfully removed. Donors should not be permitted to change their minds later, nor to impose conditions on the donation, other than as part of the consent process. ${ }^{105}$ Thus, a donor who wishes tissue to be used in one type of research but not another should be permitted to state that at the outset but should have no right to specify conditions later. If the directions are not followed, the remedy should be personal and not proprietary - ie an action for breach of contract (or possibly, breach

\footnotetext{
${ }^{104} \mathrm{Cf}$ the causes of action in Moore, above n 23.

${ }^{105}$ An agreement could be made to compensate voluntary patient groups and charities which can be instrumental in galvanising a research community to become interested in their condition and in organising the patient resources that researchers need. See Skene, above n 95; M Susan Lindee, "Genetic disease since 1945" (2000) 1(3) Nature Reviews Genetics 236-241.
} 
of fiduciary duty ${ }^{106}$ ), rather than an action to have the organ or tissue returned, used in another way, or destroyed. The sense of this principle is apparent when one considers the donation of an organ on condition that it is given to a white recipient ${ }^{107}$ and the donor discovers that this has not occurred!

\section{Tissue removed from a living person under statutory or court authority without the person's consent}

When we come to tissue removed, retained and possibly used without consent from the person from whom it was taken, different considerations arise. The lawful authority to deal with the tissue is statutory, or a court order. It is not the person's consent. The person does not have the same personal autonomy rights to be informed and to refuse. Yet there is no reason why a proprietary right should not arise in favour of the person or body holding the tissue. Indeed the argument is even stronger in this case than where the tissue has been removed with consent, since the person is clearly not entitled to retrieve, or to give directions concerning, tissue taken for forensic purposes without consent. Equally however, the restrictions on this proprietary interest are even greater than those on tissue taken consensually. Whereas tissue taken with consent may be used for any purpose authorised by the consent, tissue taken under a statute or court order must be used only for the purposes for which the legislation was enacted or over which the judge has jurisdiction. ${ }^{108}$ Samples taken from car drivers for blood alcohol testing, or from alleged offenders for identification, should not be used in research. The only circumstances in which they should be permitted to be used in a way other than for their direct statutory purpose is where a proposed use can be justified as ancillary to that purpose, such as checking equipment and skills, on a principle similar to that of implied consent discussed above.

\section{E. Body parts and tissue removed from deceased people under statutory authority without consent from the deceased during life or the next of kin}

The same principles should be applied where body parts and tissue are removed from corpses without consent under coronial legislation. The Coroner's role is to determine the cause of death and, if necessary, the identity of the deceased. A coronial postmortem may be undertaken without consent and even in the face of objection from the deceased before death, or the next of kin later. As a matter of statutory construction, however, the coroner's role is complete when the cause of death and the identity of the deceased have been determined. ${ }^{109}$ Subject to the need to retain body parts or

\footnotetext{
${ }^{106}$ This was claimed in Moore, above n 23. Although the doctor-patient relationship has not been held to be fiduciary in the UK or Australia, fiduciary obligations of doctors were recognised in Breen $v$ Williams (1996) 186 CLR 71 (HCA). One duty is not to take advantage of the doctor-patient relationship (Brennan $\mathrm{CJ}$ at 83); and an action might lie to account for profits and make good losses if that duty is breached (Gaudron and McHugh JJ at 113). Cf D Morgan, above n 86, p 102; a patient might sue for negligent non-disclosure of the prospect of monetary gain; or for unjust enrichment..

${ }^{107}$ Such a condition was imposed by the family of an English donor in 1998; DOH, above $n$ 81, paras 4.4 , 4.6. It has now been recommended that organs should not be accepted on such conditions: id para 6.1. The reason is that the National Health Service "could be breaking the law [under the Race Relations Act] if it did not ignore [such conditions]": id para 1.10; also para 5.3.iii; and possibly also the donor: para 5.3.iv. The only condition that should be imposed is one specifying which organs may be taken: id para 1.09 .

${ }^{108}$ Cf the Bristol Report: a Coroner is functus officio when an investigation is completed and has no authority to retain tissue: above nn 59-62 and text.

${ }^{109}$ Ibid.
} 
tissue for further investigation or use in evidence in court proceedings (also within the role of the coroner), the coroner has no authority to retain the tissue after the investigation has been concluded. ${ }^{110}$ The coroner's proprietary right must then yield to the right of the next of kin to possession of the body and body parts for the purpose of burial or cremation. (assuming they choose to exercise that right, which they may not with some excised body parts).

However, I have suggested earlier that the right to possession of the body for burial or cremation should extend only to the body itself and to body parts needed for burial, not to tissue held on slides or in other preserved form. ${ }^{111}$ This means that there is a gap - the Coroner does not have lawful authority to hold the tissue after the coronial investigation is completed but the next of kin do not, on my proposal, have the right to possession of it. Although the Coroner (or, more likely the pathologist) would be relatively secure in holding and using the tissue on the basis that their right to possession could be challenged only by someone with a better right to possession of it, $^{112}$ the matter may be better placed beyond doubt by statutory intervention.

\section{F. Summary of my proposed principles for what the law should be}

In summary, I propose that the law should reflect the following principles:

- People should have a personal autonomy right not to have body parts or tissue removed, retained or used without being properly informed and given the opportunity to refuse (except where tissue is removed with statutory authority or under a court order).

- The same principle should apply to body parts or tissue removed during life or after death, with the right to refuse being available to the person and the next of kin.

- If they consent, they should be entitled to impose conditions on the use of the body parts or tissue, as part of their personal autonomy right, and to seek damages if their direction is flouted.

- It is a matter of public policy whether they should be entitled to impose a condition that they should be paid. If that is permitted the right to payment should be limited to a personal right and not be enforceable in relation to the retained body parts, tissue or their products; or against people who later acquire those things.

- Body parts or tissue removed after information and consent should be subject to proprietary rights (ownership and control) in favour of the person or body holding them pursuant to the consent.

- The proprietary right in relation to body parts needed for burial or cremation should include the right to hold, insure, dissect or otherwise use, display and dispose of them, subject to the next of kin's right to possession on request for burial or cremation.

\footnotetext{
110 The Bristol Report favoured this view: n I above, para 147.

111 The Alder Hey Report made the same distinction: above $\mathrm{n} 77$ and italicised section in text.

${ }^{112}$ Cf Bristol Report para 148: if the pathologist is regarded as having the best claim to possession of the tissue, then he could exercise work or skill and take advantage of the Doodeward exception. The Inquiry does not advocate this approach: para 153.
} 
- The proprietary right in relation to tissue should include the rights to hold, insure, use, exploit, donate, sell, or otherwise dispose of it. All people holding and using the tissue should be bound to use it for medical or scientific purposes and to observe ethical standards (monitored by ethics committees). Breaches should be actionable by the person from whom the tissue came or a relative who has suffered injury because of the breach.

- The people from whom the body parts or tissue came, and their next of kin, should have no proprietary rights over them except for the right of the next of kin to gain possession of the body or body parts (not tissue) for burial or cremation.

- Body parts or tissue taken from a living person without consent under a statute or court order should be required to be used only as authorised by the statute or court order.

\section{A LEGAL REGIME TO IMPLEMENT MY POLICY PROPOSALS}

A legal regime that might provide the answers that I have suggested above as being intuitively "right", drawing upon the case law and Inquiries I have described, is based on the current common law in some aspects but would require legislation in others.

A. The personal autonomy right (during life or after death) not to have body parts or tissue removed, retained or used without being properly informed and given the opportunity to refuse

This right incorporates the general right that people have under the common law not be touched without their consent or other lawful authority (the law of battery); and the right to be properly informed about what is proposed before consenting to a medical procedure (the law of negligence). Although little consideration has been given to conditions that may be imposed when giving consent for a medical procedure, that seems implicit in the very nature of a consent. One may consent to some things but not others (eg to surgery but not to a blood transfusion). Written consent forms for participation in medical research often include provision for selection of projects. For this reason, it is not necessary to legislate to protect people's right to be consulted and to refuse. If desired, it could be supplemented by procedural guidelines to assist clinicians and others regarding the matters on which information should be provided.

Whether people should be legally entitled to require payment for allowing their body, body parts or tissue to be used in teaching, research or other medical or scientific purposes is a policy issue that may need legislation. This could be effected simply by a statutory prohibition on people selling, attempting to sell, advertising for sale etc their own bodies, body parts, tissue, other bodily material or products from any of these things. "Sale" could be defined to include all commercial transactions whether in exchange for money or other consideration. Reference could also be made to sales by personal representatives, next of kin or relatives of deceased people. Sales of hair could be exempted.

Note that the offence would consist of people selling their own bodies or bodily material. As explained in the next section, I do not recommend a total ban on commercial dealings with these things. Rights to possession, control, buying, selling, lending etc are implicit in the proprietary rights I propose in favour of hospitals, research institutes and their staff outlined below. 
The implications of restricting the rights that people have to personal rights rather than proprietary rights are very important. Tissue - or bodies or body parts - that have been retained after proper information and consent for medical or scientific purposes would then be free from proprietary claims by the people from whom they came (or their personal representatives, heirs, successors or, in the case of genetic material or information, blood relatives). But there may be circumstances in which a relative should be entitled to a remedy; for example, if a person or body later holding or using retained tissue, body or body parts uses it for purposes other than medical or scientific ones, ${ }^{113}$ or breaches confidentiality. ${ }^{114}$ Since these people would not be parties to the initial relationship between the person from whom the tissue, body or body parts came, they could not sue in contract and probably not in negligence. ${ }^{115}$ However, an action in equity is conceivable, for breach of fiduciary duty, ${ }^{116}$ or for breach of confidence. ${ }^{117}$ This would also allow substantial damages to be awarded if the wrong has already occurred, ${ }^{118}$ or an injunction to be granted to prevent it occurring. They could not however, retrieve the tissue, body or body part or require it to be destroyed, even if it was unlawfully acquired. ${ }^{119}$

\section{B. Proprietary rights in favour of hospitals etc lawfully acquiring body parts and tissue}

The principal area in which legislation would be necessary to implement the proposals I have made in this paper concerns proprietary rights in favour of hospitals, research institutes and their staff; and successors of these bodies and people. These rights would accrue when they acquire bodies, body parts and tissue from the people concerned after they have been properly informed and have consented to their use for medical and scientific research. If this is left to the common law, the principles will be uncertain and haphazard. ${ }^{120}$ Instead of agonising over whether human bodies, body

\footnotetext{
${ }^{113}$ Eg a retained organ could be "artistically enhanced" and displayed in an exhibition; $c f R v$ Gibson; $R$ v Sylveire [1990] 2 QB 619 (earrings made from two human foetuses exhibited).

${ }^{114}$ Eg genetic information from the Mo cell line could be revealed to the press or other people, with implications for Mr Moore's family, as well as himself.

115 Professors Kennedy and Grubb doubt that proximity could be established in a negligence action even by parents who discover a deceased child's organs have been retained: above n 11, at p 1849.

116 See above $n 106$.

${ }^{117}$ On the basis that anyone receiving preserved tissue or genetic information must be aware that it is accompanied by an obligation of confidentiality.

${ }^{118}$ Usually damages would not be awarded for distress, eg on learning what has occurred. However, if a person has lost employment or is not able to obtain insurance because eof an unlawful disclosure, the damages might be significant. Restitutional damages, for a share of profits, might also be possible in future.

${ }^{119}$ Cf Bristol Report, Annex B paras 128-130: executors are not entitled to possession of tissue not needed for burial even if it was not lawfully acquired initially.

${ }^{120}$ Eg what constitutes the "lawful exercise of work or skill” (Doodeward (above n 9), Dobson, above n 29)? In Kelly, anatomical specimens were recognised as property because they had been preserved, fixed or dissected for exhibition or teaching purposes; yet in Dobson (above n 29), preservation of the sample in paraffin wax was not recognised as making that tissue property. When does tissue become "a novel item with a use of its own”, a test suggested by Andrew Grubb, above n 94; or something factually and legally distinct from the cells taken from [a person’s] body” (Moore , above n 23, Panelli J)?
} 
parts and tissue can be property, ${ }^{121}$ we need clear principles on who has proprietary rights ${ }^{122}$ in respect of them, including the right of possession, control, use and commercial exploitation. ${ }^{123}$

For the reasons I have given earlier, I believe that the law should clearly support the proprietary rights of hospitals, research institutes and their staff and that these rights should be extensive. Once a person (or next of kin) has been properly informed and has consented, the only limit on the proprietary right of those lawfully in possession of the tissue should be the executor's right to possession of the body (or body parts needed for burial) for burial or cremation, after other authorised uses have been completed. This restriction should not apply to tissue on slides or otherwise preserved.

\section{Executors' right to possession of corpse and body parts for burial or cremation}

The right of executors or personal representatives to obtain possession of a body for the purpose of burial or cremation is well established at common law and should not be altered. ${ }^{124}$ It should include the right to possession of body parts that one might reasonably expect to be buried or cremated with the body, but not tissue on slides which is not needed for burial. ${ }^{125}$ Despite the lack of certainty in deciding which parts or tissue are, or are not, needed for burial, the concept could probably not be improved by legislation. ${ }^{126}$ It will be a matter for decision in each case.

\section{Bodies, body parts or tissue removed, retained or used under a statute or court order should be dealt with only in accordance with the relevant authority}

Finally, bodies, body parts or tissue removed, retained or used under a statute or court order should be dealt with only in accordance with the relevant authority. This restriction seems implicit in a statutory instrument but, if there is doubt, an appropriate provision could be inserted in each statute or court order to make it clear what use may be made of retained tissue. ${ }^{127}$

\footnotetext{
${ }^{121}$ Judges have recognised that tissue removed from the body is property for some purposes: forensic testing (Roche above $\mathrm{n} 31$ ); theft (Kelly, above n 10; Rothery, above $\mathrm{n} 18$ ) and patenting of biological inventions (Moore, above n 23).

122 The notion of property is essential to ownership but not to other proprietary rights; eg in Doodeward (above n 9), the court referred to an executor's right to possession of a corpse for burial even though there could not be property in a corpse (subject to the work and skill exception).

${ }^{123}$ Cf Andrew Grubb, above n 94: English law is less concerned with ultimate title (ownership) than with rights associated with possession.

${ }^{124}$ Above $\mathrm{n} 11$ and text. Note the people who may be entitled to possession of a body: above $\mathrm{n} 11$.

${ }^{125}$ Cf Bristol Report, Annex B paras 128-130: An executor's right to possession of a body arises from the duty to bury the body, not necessarily parts of the body, or tissue in tissue banks.

${ }^{126}$ The Alder Hey parents apparently favoured the definitions in the Concise Oxford Dictionary: "Tissue: A collection of cells specialised to perform a particular function.; Organ: a part of the body composed of more than one tissue that forms a structural unit responsible for a particular function”: Alder Hey Report ch 11, 1. However, I do not believe that all parts of the body except tissue in this narrow sense are "needed for burial". This could be left for decision in each case to accord with the wishes of particular people.

${ }^{127}$ Eg Human Tissue Act 1982 (Vic) s (3): “An order by a coroner under the Coroners Act 1985 (Vic) directing a post-mortem examination is ... authority for the use, for therapeutic, medical or scientific purposes, of tissue removed from the body of the deceased person for the purpose of the post-mortem examination” (emphasis added). This permissive form of authority may be less acceptable in the UK, post Bristol and Alder Hey. Even in Victoria, there is reluctance to use tissue removed at post-mortem for other purposes without specific consent despite the statutory authority to do so.
} 


\section{E. CONCLUSION}

The regulatory context in which the law has been developed and policy recommendations have been made concerning proprietary rights in human bodies, body parts and tissue has led to inconsistencies, However, this paper has identified some common principles. Evaluating the statements of the law and the proposals for change, I have suggested what the law should be (summarised in the dot points in Part $8 \mathrm{~F}$ above); and suggested a legal regime to implement my policy proposals (Part 9 above). 
Proprietary rights in human bodies, body parts and tissue: Regulatory contexts and proposals for new laws

\section{Loane Skene}

Professor of Law, Faculty of Law and Faculty of Medicine, Dentistry and Health Sciences, University of Melbourne; Program Director, Medical Ethics, Centre for Applied Philosophy and Public Ethics (CAPPE), Charles Sturt University and University of Melbourne; Deputy Director, Centre of Law and Genetics, University of Tasmania and University of Melbourne.

Address:

Faculty of Law

University of Melbourne

Parkville 3010

Australia 


\section{University Library}

\section{- M M N E R VA A gateway to Melbourne's research publications}

Minerva Access is the Institutional Repository of The University of Melbourne

Author/s:

SKENE, LOANE

Title:

Proprietary rights in human bodies, body parts and tissue: regulatory contexts and proposals for new laws

Date:

2002

Citation:

Skene, L. (2002). Proprietary rights in human bodies, body parts and tissue: regulatory contexts and proposals for new laws. Legal Studies, 22(1), 102-127.

Publication Status:

Published

Persistent Link:

http://hdl.handle.net/11343/33402 